\title{
INFORMATION SYSTEMS AND TECHNOLOGIES
}

\author{
DOI https://doi.org/10.30525/978-9934-588-79-2-1.1 \\ УДОСКОНАЛЕННЯ ОПИСУ \\ ФУНКЦІОНАЛЬНОЇ МОДЕЛІ ТЕХНІЧНОГО ОБ'ЄКТУ
}

\author{
Антипенко В. П. \\ кандидат технічних наук, \\ старший викладач кафедри комп'ютерних наук \\ Сумського державного університету \\ Неня В. Г. \\ кандидат технічних наук, доцент, \\ доиент кафедри комп'ютерних наук \\ Сумського державного університету \\ Ковпак А. Ю. \\ аспірант кафедри комп'ютерних наук \\ Сумського державного університету \\ м. Суми, Украӥна
}

Вступ. Важливим напрямком розвитку техніки є поступове витіснення людини як із контуру виконання робіт, так і з контуру управління виконанням робіт. Отже, актуальною є задача розвитку засобів механізації та автоматизації, що вимагає розвитку методів моделювання, які є основою виконання аналізу та проектування об'єктів проектування. Даний напрямок розвитку техніки передбачено стратегією розвитку промисловості в рамках програми Industry 4.0 і підтримується міжнародним консиліумом системних інженерів.

Обгрунтування базового методу моделювання технічних об'єктів як систем. Методика функціонального моделювання розроблена в США за програмою комп'ютеризації промисловості ICAM (Integrated Computer-Aided Manufacturing). Вона отримала назву IDEF (Integrated Definition) [1]. Деякі з цих методик отримали статус державного стандартів навіть і в інших країнах.

До IDEF входять різні методики, наприклад, функціонального, інформаційного моделювання та моделювання поведінки [2]: IDEF0 метод моделювання функцій, IDEF1 i IDEF1X - методи моделювання даних, IDEF2 - метод імітаційного моделювання, IDEF3 - метод опису процесу та опису стану об'єкта, IDEF4 - метод об'єктно-орієнто- 
ваного проектування, IDEF5 - метод опису онтології, IDEF6 - метод обгрунтування дизайну, IDEF8 - метод опису взаємодії людини з системою, IDEF9 - метод опису обмежень, IDEF14 - метод моделювання мереж. IDEF-технології успішно застосувуються й демонструють ефективні засоби аналізу, конструювання та відображення бізнеспроцесів.

IDEF0 призначена для функціонального моделювання [3]. При цьому моделюється виконання функцій об'єкта шляхом створення графічного опису моделі. Це дозволяє з'ясувати, що, як, ким і за допомогою чого робиться для виконання функції. B IDEF реалізовані три базові принципи моделювання процесів [1]: принцип функціональної декомпозиції; принцип обмеження складності; принцип контексту.

Разом $з$ тим, усім наведеним методам притаманні наступні недоліки: відсутня можливість перевірки та аналізу розроблених моделей формальними методами за формалізованими ознаками; відсутня можливість визначення показників модельованих або проектованих об'єктів за допомогою формальних методів. На часткове подолання вказаних недоліків і направлені дослідження, результати яких наводяться у даній публікації.

Вимоги до методу функціонального моделювання технічних об'єктів. Для обрання напрямку удосконалення методу конкретизуємо вимоги до функціонального моделювання технічних об'єктів, оскільки функціонування технічних процесів може бути ефективно проаналізовано або обгрунтовано спроектоване за умови наявності формалізованого опису. Моделі повинні вибудовуватися за єдиними встановленими правилами однаково для усіх ієрархічних рівнів опису усіх компонентів. У процесі проектування наперед невідомо ні складу об'єкту, ні параметрів компонентів, ні способу їх об'єднання у систему. Однорідний опис дозволяє контролювати працездатність моделі на рівні інтерфейсів використовуваних функцій.

Модель повинна бути однією і тією ж без огляду на аспект їі використання: презентація при їі розробці, рецензуванні фахівцями різного профілю, опрацюванні програмними засобами, використанні у процесі проектування. Модель та їі параметри повинні самі себе презентувати i бути само документованими. Модель після узгодження та затвердження повинна бути самодостатньою і використовуватися без впливу суб'єктивного фактору.

Графічна та математична форми моделі. Приймаємо основну частину вимог методу IDEF0 та графічний вигляд функціональної моделі. Технічний об'єкт виконує функцію $F$. Модель успадковує 
традиційні елементи: вектори вхідних параметрів $X$, вихідних параметрів $Y$, параметрів управління $C$, параметрів використовуваного механізму $M$ та два додаткових вектори: вектор параметрів зовнішнього середовища $P e$, які технічний об'єкт використовує для налаштування свого функціонування в умовах, які змінюються, та параметри внутрішнього стану $P i$, які використовує система управління технічним об'єктом, для коригування його роботи.

Функція $F$ представляє рівняння або систему рівнянь необхідного типу для опису робочого процесу обраного об'єкта та пов'язує між собою узгоджені значення усіх параметрів і у вигляді (1):

$$
F(X, Y, C, M, P e, P i),
$$

яке використовується у процесі проектування об'єкту та при його експлуатації (практичному застосуванні). По суті це математична система рівнянь.

При моделюванні функціонування технічного об'єкту на рівні контексту застосовуються інформаційні технології для введення та зберігання усіх стандартних по IDEF0 атрибутів контекстної діаграми, а також чисельних значень параметрів та формалізований опис виконуваної функції, який є придатним для опрацювання трансляторами алгоритмічних мов програмування.

Аналітична форма декомпозиції функції технічного об'єкту. Головна функція технічного об'єкта при необхідності піддається декомпозиції. Крім рекомендацій IDEF0, слід прийняти до уваги, що кожну введену при декомпозиції функцію повинен виконувати компонент технічного об'єкту, який по можливості повинен бути готовим або стандартним (уніфікованим) виробом. Це суттєво зменшує кількість можливих варіантів декомпозиції.

Будемо використовувати позначення функції символом $F$. Функціональне моделювання технічних об'єктів має ту особливість, що принципове, концептуальне значення мають перші декілька кроків декомпозиції, які вимагають обговорення, рецензування, погодження та затвердження. Далі використовуються напрацьовані досвідом інженерів та вчених рекомендації, типові проектні рішення для модулів, блоків, збиральних одиниць та деталей. За цих умов для інженерів проектантів зручно використовувати аналітичні структурні формули. Будемо їх складати керуючись наступними правилами, які обрані для зручності обробки аналітичних виразів програмними засобами та збереження їх семантичного змісту: 
$F$ - проста функція. Простою вона $\epsilon$ у тому сенсу, що для іiї реалізації існує готовий пристрій, апарат, машина, компонента тощо. Проектування у цьому випадку виконується за один технологічний крок.

$[F]$ - складена функція. У подальшому вона повинна піддаватися декомпозиції, оскільки для іiї практичної реалізації немає готових складових.

$[F 0]=F 1+F 2-$ складена функція $F 0$ реалізується послідовним виконанням функції $F 1$ та функції $F 2$. Вхідний потік $X$ для $F 0$ попадає на вхід $F 1$. Вихідний потік $F 1 \in$ вхідним потоком для $F 2$. Вихідний потік $F 2 є$ одночасно вихідним потоком для $F 0$. Управління та механізми розподіляються необхідним чином. Для $F 1$ та $F 2$ складаються формули типу (1) в залежності від мети проектування та вимог технічного завдання. Усі параметри чисельно узгоджуються між собою. Це надалі передбачається для усіх випадків.

$[F 0]=F 1^{*} F 2$ - складена функція $F 0$ піддається декомпозиції за допомогою двох функцій $F 1$ та $F 2$, які виконуються паралельно.

Для моделювання зміни послідовності виконуваних функцій при моделюванні, а потім і при експлуатації (використанні) технічного об'єкту вводиться функція $I F$ із наступною семантикою, яка є характерною для мов програмування, $I F(C, F 1, F 2)$. Якщо значення умови $C$ (Condition) $\epsilon$ істина, то реалізується функція $F 1$, а у іншому випадку - функція $F 2$.

Елементи використовуваних інформаційних технологій. Паралельно до візуального опрацювання функцій, які виконує технічний об’єкт, формується їх інформаційна модель, яка власне і обробляється програмними засобами в процесі моделювання та використання від час експлуатації технічного об’єкту.

Вимога вільного доступу до моделі та реалізація самодокументування реалізуються через технологію XML. Основу складають описи одного параметра та функції із однієї формули. Із них формуються множина параметрів і множина формул. Уже із цих двох множин та зв'язків між ними формується математична модель, за допомогою якої виконується імітація функціонування обраного об'єкту.

Практичне застосування запропонованого методу функціонального моделювання апробовано в роботі [4]. Було спроектовано, виготовлено та досліджено контролер для системи регулювання теплопостачання будинку.

Висновки. У ході виконання даного дослідження було удосконалено методику функціонального моделювання IDEF0 відносно моделювання технічних об'єктів. Запропоновано інформаційний опис функцій, аналітичну форму представлення моделі з можливістю відтво- 
рення деревоподібної їі структури. Подальші дослідження доцільно провести у напрямку автоматизації планування та виконання комп'ютерного моделювання технічного об'єкта або його обраної частини.

\title{
Література:
}

1. IDEF Family of Methods. URL: http://www.idef.com (дата звернення: 15.09 .2020 ).

2. Serifi V. et al. Functional and information modeling of production using IDEF methods. Strojniški vestnik. 2009. T. 55. - №. 2. - C. 131-140.

3. Jeong K. Y., Wu L., Hong J. D. IDEF method-based simulation model design and development. Journal of Industrial Engineering and Management. 2009. - T. 2. - №. 2. - C. 337-359.

4. Antypenko V. et al. Functional Modeling of the Means for Heat Consumption Monitoring During Its Design Using the Information. International Conference «New Technologies, Development and Applications». Springer, Cham. 2020. - C. 701-708.

DOI https://doi.org/10.30525/978-9934-588-79-2-1.2

\section{ІНТЕРПРЕТАЦІЯ РЕЗУЛЬТАТІВ ПРОГНОЗУВАННЯ ОТРИМАНИХ ВИПАДКОВИМ ЛІСОМ}

\author{
Бабенко В. О. \\ бакалавр комп'ютерних наук, \\ магістр кафедри біомедичної кібернетики \\ Національного технічного університету Украйни \\ «Київський політехнічний інститут імені Ігоря Сікорського» \\ Носовець О. К. \\ кандидат технічних наук, \\ дочент кафедри біомедичної кібернетики \\ Національного технічного університету Украӥни \\ «Київський політехнічний інститут імені Ігоря Сікорського» \\ Тищенко Б. В. \\ бакалавр комп'ютерних наук, \\ магістр кафедри теорії та технології програмування \\ Київського начіонального університету імені Тараса Шевченка \\ м. Київ, Україна
}

